\title{
ASSESSMENT OF THE RIVER HABITAT QUALITY WITHIN EUROPEAN WATER FRAMEWORK DIRECTIVE: APPLICATION TO DIFFERENT CATCHMENTS IN CZECHIA
}

\begin{abstract}
M. M a to u š k ová: Assessment of the river habitat quality within European Water Framework Directive: Application to different catchments in Czechia. - Geografie-Sborník ČGS, 113, 3, pp. 223-236 (2008). - The paper presents the method of ecomorphological assessment of river habitat quality EcoRivHab, based on field mapping with possible usage of distance data. EcoRivHab is a tool used to assess the state of streams which lays an emphasis on hydromorphological characteristics of channel, ecohydrological state of the riparian belt and flood plain. Definition of the local reference state of the river habitat in the given physiographic region serves as a precondition. Overall ecohydrological state is evaluated by five degrees (ES I-V), characterizing the state of the watercourse in the context of the EC Water Framework Directive. The goal of this research was to assess the ecohydromorphological state of selected catchments in Czechia, representing varied relief types, and at the same, representing landscape with differing degrees of anthropogenic impact.
\end{abstract}

KEY WORDS: EcoRivHab - river habitat - ecohydrological principles - ecomorphological assessment - reference state - Czechia.

The presented research was realized under financial support of Czech Science Foundation projects 205/05/P102 "Ecohydrological Monitoring of the River Habitat Quality in the Context of EC WFD" and the MSM research project 0021620831 "Geographic Systems and Risk Processes in the Context of Global Changes and European Integration".

\section{Introduction}

As part of the GAČR (Grant Agency of the Czech Republic) project „Assessment of Ecohydrological State of Streams in the Context of the Water Framework Directive 2000/60/EC“, the following method was formulated: "Ecomorphological Assessment of the River Habitat Quality" (EcoRivHab), stemming from the ecomorphological monitoring method of habitat quality of small streams in the hilly relief (Matoušková 2003, 2004). In order to arrive at broader application possibilities and due to the requirement to fulfil the Water Framework Directive (hereinafter WFD; EC, 2000) and ĆSN EN 14614, 2005 criteria, its adaptation was performed.

The main goal of the research was to assess the ecohydromorphological state of streams, identify reaches which meet the so called good ecological state according to WFD, at the same time, to find watercourse reaches showing strong anthropogenic impact, as well as to find localities with natural or nearly natural habitat of water ecosystems. The objectivity and correctness of obtained results had to be tested by the application of different 
assessment methods. Important output of realized research is the comparative analysis of applied methods.

\section{Applied Methods}

The EcoRivHab method (Matoušková 2007) was used as the point of departure to assess the stream habitat quality. Within the framework of individual study river basins, foreign methods were tested, as well: Gewässerstrukturgütekartierung LAWA - Field Survey (LAWA 2000); LAWA - Overview Survey (Kern et al. 2000); Rapid Bioassessment Protocol RBP (Barbour et al. 1999); Channel Assessment Procedure Guidebook - CAP (Ministry of Forest BC 1996); and comparative analysis of the outputs obtained was performed. HABSCORE and LAWA Field Survey (LAWA-FS) methods, as well as the EcoRivHab method, are based on field investigation with possible utilization of distance data, e. g. aerial or satellite images, specific layers of digital maps. The LAWA Overview Survey (LAWA OS) method is based on interpretation of distance information sources and other materials from river authorities. The field investigation is of supplementary nature only. The CAP method is part of the assessment block Watershed Assessment Procedure (WAP, B.C. Ministry of Forest and Ministry of Environment). It uses aerial images and field mapping in the assessment, focused on determining basic morphological types of riverbeds, not on assessing the habitat quality. It was used in connection with the study of fluvial-morphological processes of natural streams.

Within the framework of water bodies quality assessment in European Union countries, ecohydrological principles are of crucial importance. The so called ecological state is the basis in assessment of stream quality, defined based on hydromorphological, hydrochemical and hydrobiological parameters. Currently, monitoring of water formations habitat quality, of typology and definition of reference states of streams is being performed in individual membership countries. CEN EU formulated instructions to assess morphological situation of the riverbed, riparian belt and flood plain (CEN 2002) and created a directive to assess hydromorphological parameters of streams (EN 14614, 2004), implemented subsequently in the national legislation of EU membership countries (Weiss et al. 2007).

\section{EcoRivHab Method Characteristics}

The EcoRivHab method contains in a marked extent the assessment parameters pursuant to WFD. It includes analysis of hydromorphological characteristics of streams, analysis of the flow dynamics degree, of surface water quality, riparian belt vegetation, land use of flood plain, and other ecohydrological characteristics of the river basin. The method is based on definition of a local reference state. The assessment is performed in urban as well as rural areas. The water ecosystem is viewed as a broader area, formed by individual zones, integrated in the assessment (Matoušková, Mattas 2003). Thus the monitoring is not related to the riverbed only. Optimally, the spatial unit of the highest order should be represented by the whole river basin, as all processes occurring therein are reflected in qualitative and quantitative characteristics of the whole water ecosystem. The flood plain is a unit lower 
by one order, assessed in field investigation, and/or using distance data. Combination of both approaches is optimal. The field mapping concerns flood plain, the riparian belt and the channel.

The riverbed zone is formed by two components: water (pelagial) and the channel, formed by the so called interstitial and the amphibic part. The channel has an ecologically important function as it creates a mosaic of small biotopes for water organisms with varied flowing, bottom structure elements, various light differences etc. The bank vegetation is formed by watersides of the channel. Delimiting of the bank vegetation in small watercourses is quite difficult as it is relatively narrow, individual littoral zones thus cannot be always distinguished with sufficient clarity, thus distinguishing the bank vegetation and the riparian belt. Its width is variable depending on the cross profile shape.

The zone of riparian belt (includes a vegetation belt along the channel, and forms part of the terrestric area. From the geomorphological point of view, it is part of the flood plain; however, from the ecological viewpoint, it is suitable to delimit this zone separately. For the purpose of EcoRivHab, the borderline of riparian belt was not determined firmly. However, at the minimum, it should achieve the width of $10 \mathrm{~m}$ from left and right river bank. The width dimension of the bed, the river valley type and the whole flood plain type are determinant for an optimum choice of the size.

The flood plain zone is linked to the riparian belt. Its outer borderline can be delimited based on geomorphological characteristics. In areas of great human impact where the borderline cannot be delimited in a simple way, the minimum width of $100 \mathrm{~m}$ from the channel is recommended.

The river basin as the highest spatial ecohydrological zone includes all processes occurring in the given area, which have a direct or indirect impact on ecohydrological characteristics of the watercourse (e.g. surface water quality, erosion susceptibility of the land, outflow and stream bed load regime). The river basin boundary is delimited by the orographic watershed divide, and/or specified closer in small river basins by the hydrogeological watershed divide.

Delimiting of borderlines of individual zones is not of crucial importance; however, understanding of the watercourse as an integrated water ecosystem is important, showing a close interconnection between the aquatic and terrestrial part. The meaning of borderline areas between individual biotopes should be thus emphasized, as well as the importance of interconnection of the surface and underground outflow, together with the flow of substances.

\section{Data Sources}

The landscape where mapping is performed represents the basic source of information. This cannot do without available mapping resources, of course, which are as follows: Basic topographic map of Czechia 1:10,000; basic water management map 1:50,000; specific layers of the DiBaVod database 1:50,000 and 1:10,000 (Water Research Institute, Prague), and/or the digital terrain model DMÚ-25 (Czech Geodesic and Cadastral Office, Prague). Utilization of available information from watercourse authorities is suitable, as well, e.g. concerning the riverbed modifications performed. Within the research, aerial orthophotometric images in the digital form were used, as well, with the resolution of $50 \mathrm{~cm}$ (GEODIS), and the possibility of application of 
panchromatic and multispectral satellite images QuickBird (ArcData) was tested, having the resolution of $0.6 \mathrm{~m}$ in panchromatic and $2.4 \mathrm{~m}$ in multispectral images. The complex ecohydrological assessment should also include an analysis of the rainfall-runoff regime data, assessment of surface water quality, contamination of sediments, and/or other indicators.

\section{Field Mapping}

Mapping is performed along the entire length of the watercourse, as a rule from the spring to the mouth. Partial reaches are monitored, the lengths of which are determined firmly, and the beginning and end of the given reaches is laid down clearly in the map and determined using GPS. Their mutual overlapping may not occur. It is recommended to perform mapping in lengthheterogeneous reaches, while laying an emphasis on their qualitative homogeneity. The length of individual reach should be in the range of $100-1,000 \mathrm{~m}$ in an optimum case. Every reach of the watercourse is marked using a three-character code in the map, and numbered using a three-digit number in the direction from the mouth to the spring (e.g. reach1 in the Rolava River is ROL001; reach 2 in the Rolava River is ROL002). If the watercourse branches out, each branch is assessed as well as marked separately.

Field investigation of hydromorphological structures of the riverbed should be performed during low water conditions, and before the maximum vegetation growth, in the optimum case. Mapping of riparian belt and the flood plain should be performed during the vegetation period. The mapper can use the mapping form where individual parameters are specified. The mapping results are recorded continuously in the digital working form and drawn in the graphical form in the maps. Assessment using a spreadsheet calculator follows, as well as conversion into thematic GIS layers by means of identifiers.

Chosen parameters jointly characterize the so called ecomorphological state of the watercourse. Within the framework of this methodology, monitoring of 31 parameters was proposed, associated in the group of 17 main parameters. 3 group parameters are derived from them, characterizing individual zones, and subsequently 1 resulting, the so called ecomorphological state (Table 1). The number of parameters can be optimized, i.e. an optimum number in respect of the monitoring type and purpose of assessment can be chosen.

The majority of parameters are assessed using five score-based classification (S: 1, 2, 3, 4, 5). Numeric measurement of characteristics of some parameters is difficult or their quantitative characteristics are relative. Such parameters are assessed using e.g. frequency assessment (F), expressing their relevant occurrence $(1$ - high, 3 - intermediate, 5 - low). Some parameters are of documentation nature, i.e. they are not assessed using scores (verbal assessment - V) See Table 2. All parameters have the same weight in the resulting determination of the so called ecomorphological state because the evaluation is done on the basis of additive principle. Final ecomorphological state is calculated as the arithmetical average of the evaluated three zones. The ecomorphological state is then classified on the basis of assignment of numerical result into one of the defined ecomorphological classes (see Table 3 ). The numeric result obtained is assigned verbal assessment in the conclusion, according to classification in 
Tab. 1 - Overview of mapped parameters using the EcoRivHab method

\begin{tabular}{|c|c|c|c|}
\hline $\begin{array}{l}\text { Ecomorphological } \\
\text { zones }\end{array}$ & Group of parameters & Parameters & Assessment type \\
\hline $\begin{array}{l}\text { Riparian belt } \\
\text { Flodd plain }\end{array}$ & $\begin{array}{l}\text { Morphology and } \\
\text { channel geometry } \\
\text { Longitudinal profile } \\
\text { Cross profile } \\
\text { Bottom structures } \\
\text { Bank structures } \\
\text { Surface water quality }\end{array}$ & $\begin{array}{l}\text { River valley, gradient } \\
\text { Curvature } \\
\text { Channel character and shape } \\
\text { Deepening of the channel } \\
\text { Connectivity to ground water } \\
\text { Steps } \\
\text { Erosion and accumulation forms } \\
\text { Flow patterns } \\
\text { Variation of depth (riffles a pools) } \\
\text { Modification of outflow } \\
\text { Type and stability } \\
\text { Middle profile depth } \\
\text { Variation of width } \\
\text { Profile capacity } \\
\text { Substrate type } \\
\text { Bottom modification } \\
\text { Diversity of microhabitats } \\
\text { Character of bank vegetation } \\
\text { Structure of bank vegetation } \\
\text { Bank modification } \\
\text { Stability of banks } \\
\text { Hydrochemical features } \\
\text { Hydrobiological features } \\
\text { Occurrence of sewage outlets } \\
\text { Channel vegetation } \\
\text { Existence } \\
\text { Character and structure of vegetation } \\
\text { Land use } \\
\text { Prevailing land use } \\
\text { Occurrence of flood protection measures } \\
\text { Retention capacity }\end{array}$ & 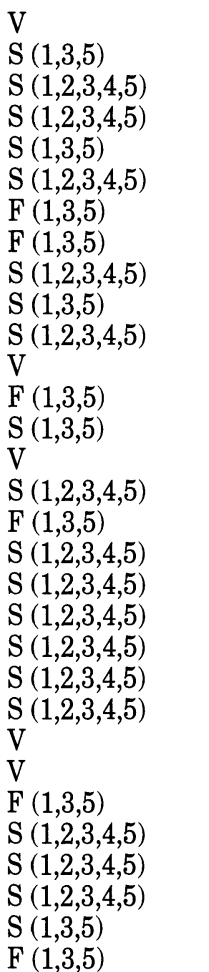 \\
\hline
\end{tabular}

Note: $\mathrm{F}$ - frequency assessment, $\mathrm{S}$ - score based assessment, $\mathrm{V}$ - verbal assessment, $\mathrm{S}$ verbal assessment

Tab. 2 - Example of verbal and point assessment - parameter curvature

\begin{tabular}{|l|l|l|}
\hline Type & Symbol & Point assessment \\
\hline Meandering & M & Natural origin \\
Sinuous with branches & SB & 1 \\
Sinuous without branches & S & Slightly modified \\
Braided & B & 3 \\
Straight & ST & Modified, new river course and riverbed \\
\hline
\end{tabular}

Note: Degree of sinuosity could be determined using Klimazewski Index $(\mathrm{Km})$

$K m=\frac{L r[m]}{L v[m]}$

$L r$ length of the river bed, $L v$ length of the valley, $K m>1.5$ meandering channel course, $K m<1.5$ sinuous channel course, $K m=1$ straight channel course.

fixed delimited and defined intervals. The graphical output is represented by thematic maps of individual group parameters and the map of an overall ecohydromorphological state of the watercourse. 
Tab. 3 - Final classification of the ecomorphological state, comparison to WFD quality classes

\begin{tabular}{|l|l|l|l|l|l|}
\hline $\begin{array}{l}\text { EcoRivHab quality } \\
\text { class (ES) }\end{array}$ & I & II & IV & V \\
\hline $\begin{array}{l}\text { Point assessment } \\
\text { Description }\end{array}$ & $\begin{array}{l}<1-1.5> \\
\text { Natural, near } \\
\text { natural } \\
\text { (unchanged) } \\
\text { blue } \\
1\end{array}$ & $\begin{array}{l}\text { Slightly } \\
\text { changed }\end{array}$ & $\begin{array}{l}\text { Moderately } \\
\text { changed }\end{array}$ & $\begin{array}{l}\text { Strongly } \\
\text { changed }\end{array}$ & $\begin{array}{l}\text { Completely } \\
\text { changed }\end{array}$ \\
$\begin{array}{l}\text { Color } \\
\text { WFD quality class }\end{array}$ & $\begin{array}{l}\text { yellow } \\
3\end{array}$ & $\begin{array}{l}\text { orange } \\
4\end{array}$ & $\begin{array}{l}\text { red } \\
5\end{array}$ \\
\hline
\end{tabular}

The summary ecomorphological state is characterized by five ecomorphological classes, hereinafter ES (ES I - natural or near natural state (reference condition); ES II - slightly changed; ES III - moderately changed; ES IV - strongly changed; ES V - completely changed). The resulting ecomorphological state documents the level of anthropogenic impact of the water ecosystem.

\section{Study Areas}

The following river basins were chosen as study areas to assess the river habitat quality: Upper Blanice River, Rolava River, Křemelná River, Liběchovka River, Košínský Brook, Rakovnický Brook, Kličcava River and Bílina River (Fig. 1). By their nature, the river basins chosen represent well the geographic diversity of the relief of Czechia, and they differ in the level of anthropogenic impact. A condition used in their selection was also represented by existence of natural or near natural localities due to the need of defining the reaches with reference condition. On the contrary, the Bílina River basin was chosen as an example of a river basin with very strong anthropogenic impact. Overall, approximately $450 \mathrm{~km}$ of streams were mapped, while in the majority of the study catchments, at least two different methods were applied. In linkage to the GAČR project, areal field investigation of streams in the Berounka River basin is still being performed

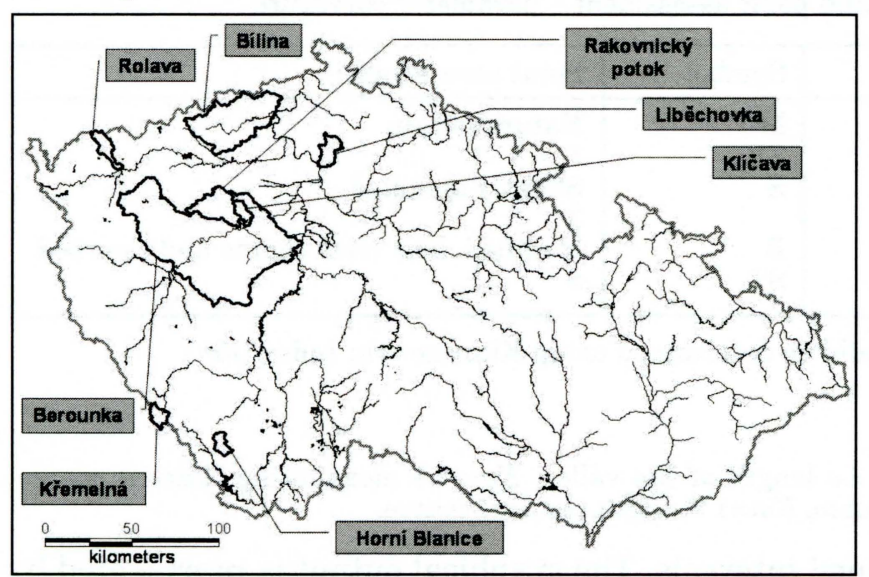
in the Křivoklát Protected Landscape Area, the administration of which showed an interested in areal mapping of the watercourse habitat quality using the EcoRivHab method. Possibilities of distance investigation are furthermore being tested in the main watercourse of the Berounka and Upper Blanice Rivers.

Fig. 1 - Location of study river basins of ecomorphological monitoring 


\section{Determination of Reference Condition}

Determination of ecological quality of the so called reference state is problematic, which can be derived from localities not affected by human activities, representing not an easy task in the today's prevailing cultural landscape of Central Europe. Based on the research performed, definition of the local reference state can be recommended, which can be suitably derived from natural or nearly natural localities found in the given or near river basin, showing identical physically geographic characteristics. To define the reference state, the following parameters are crucial: river valley type and the gradient; curvature degree; communication with ground water; erosion and accumulation forms; stability of the cross profile; width and depth profile variability; microhabitat diversity; character and structure of the bank vegetation; character and land use of riparian belt; land use and retention potential of flood plain; surface water quality (quality class I - II in the optimum case). No artificial steps (weirs and other migration barriers) and no technical flood protection measures should exist in the reference reaches. Analysis of maps and field mapping was realized for the delimitation of reaches in reference condition, which was based on above mentioned parameters. The final ecomorphological state of reaches in reference condition should not be higher than 2.

\section{Mapping Results Using the EcoRivHab Method}

It follows from the mapping performed in all river basins of interest that the best ecohydrological state is shown by the river basins of Upper Blanice, Klíčava and Liběchovka Rivers. Approximately $80 \%$ are represented by ES I and II reaches, see Figure 2, conditioned by their geographic position, considerable extent of protected areas and low proportion of anthropogenic

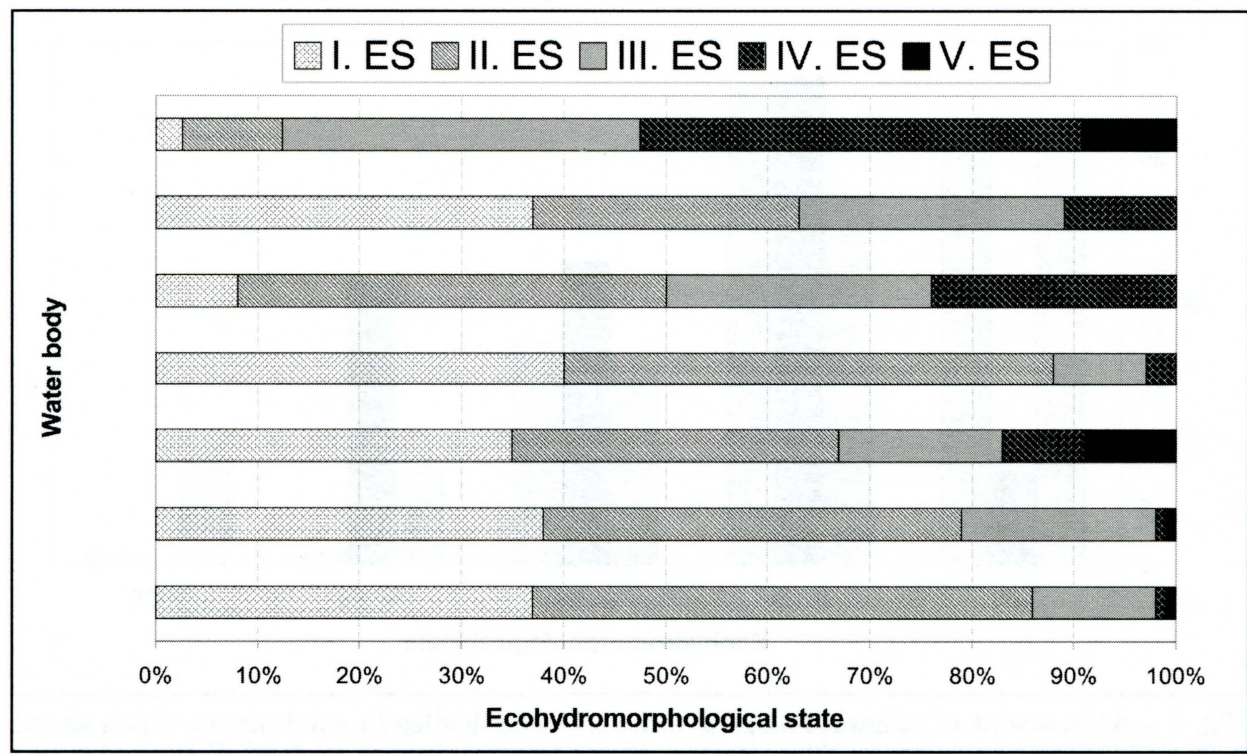

Fig. 2 - Ecomorphological state of water bodies in study catchments using the EcoRivHab method. Field mapping\&assessment: Bicanová (2005), Dvořák (2008), Lelut (2007), Matoušková (2003), Silhánová (2007), Šípek (2006) and Vondra (2006) 
activities. River basins of the Rolava River, Košínský Brook and Rakovnický Brook show a higher degree of anthropogenic modification. 10-25\% of the total length of the reaches mapped show a not very good ecohydromorphological state (ES IV and V). These are clearly reaches bound to anthropogenic activities in the river basin, no matter if built-up areas are concerned or rural landscape, used for intensive agricultural activities.

Exceptional position in ecohydromorphological monitoring is occupied by the Bílina River basin. This river basin was chosen intentionally as an example of an area with very strong human impact where the possibility of the EcoRivHab method application was tested on artificial watercourses. Numerous channel reaches are modified or displaced. Only $12 \%$ of the total length of the main Bílina River can be designated as natural or nearly natural. Except for rare cases, these reaches are situated in the mountain areas and foothills of Krušné hory (Krušné Mountains). Reaches found predominantly in České středohoří (Czech Low Mountain Range) were classified reaches with moderate human impact (ES III; $34 \%$ ). In reaches showing a quite unsatisfactory state, i.e. ES IV and V, are situated in the middle course (Jirkov - Obrnice area; Ervěnický koridor - Ervěnický Corridor) and in urban areas of cities where the channel has been modified in the greatest extent. It is alarming that the whole length of these reaches represents $51 \%$ of the total main stream length (Dvořák 2008).

The Rolava River basin can be provided as an example of the mountainousup to foothill-type river basin. Major modifications of the riverbed were performed in the middle and lower course of Rolava River, especially in order to provide flood protection measures and energy utilization by small water power plants, having a negative impact, too, on the habitat character. The

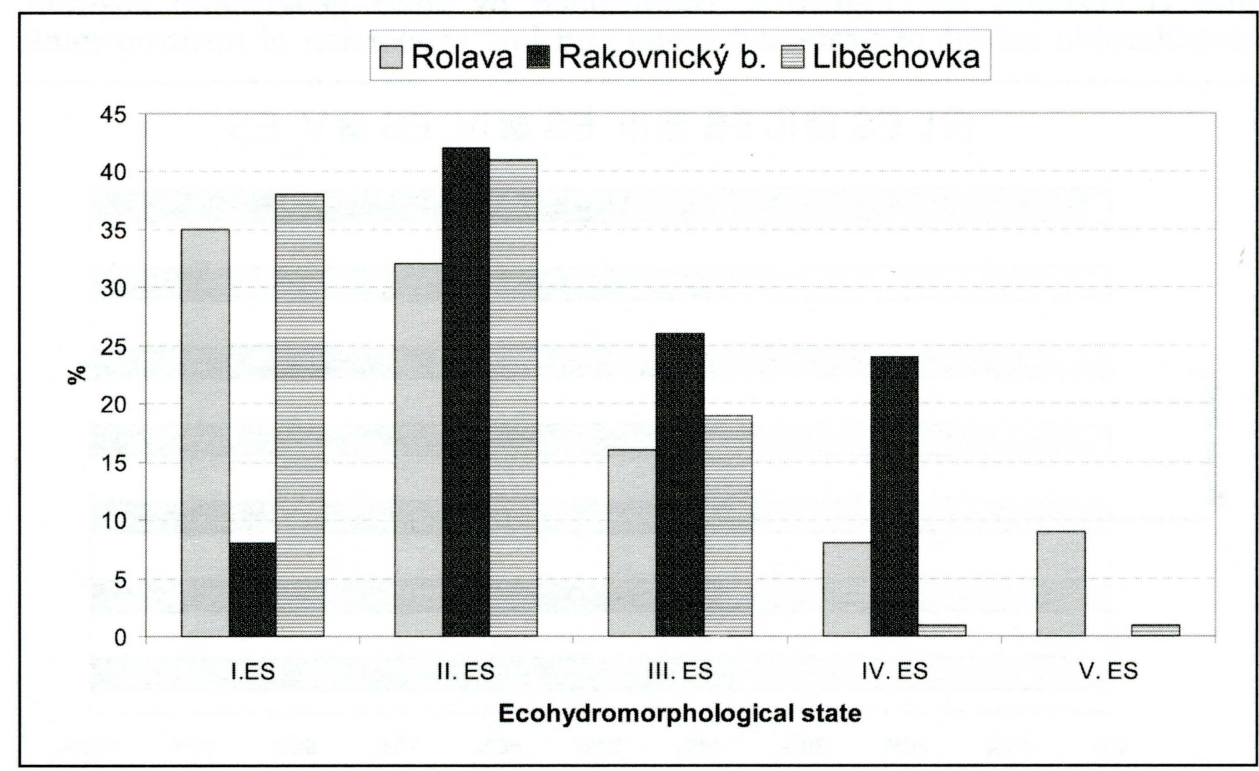

Fig. 3 - Assessment of ecomorphological state of water bodies in catchments which shows a varied relief and landuse: The Rolava River (mountainous- to foothill-type stream), Rakovnický Brook (hilly-type stream), Liběchovka River (lowland-type stream) using the EcoRivHab method. Field mapping \& assessment: Lelut (2007), Matoušková (2003), Sípek (2006) 
overall ecomorphological state in the Rolava River basin can be characterized as good. Significant differences exist between the state in upper courses, which run through mountainous and rarely settled landscape, where ES I and II prevail. The situation is unsatisfactory in the middle and lower course where the Rolava River flows through urban areas of the communities of Nejdek, Nová Role and Karlovy Vary. Here ES IV and V prevail, while these parts represent $12 \%$ of the total main watercourse length. The situation is also adverse in the Nejdecký Brook as $40 \%$ of its total length is assessed as areas with moderate up to strong anthropogenic impact (ES III and IV; Lelut 2007).

The river basin of the Rakovnický Brook can be mentioned as an example of hilly area. Overall ecomorphological state of the catchment can be characterized as not very satisfactory as almost $25 \%$ of the mapped length of the main watercourse is represented by reaches which show strong anthropogenic impact (ES IV), see Figure 3. Reaches found in the Křivoklát Protected Landscape Area show a relatively sharp contrast, where, with the exception of urban areas of small communities, ES I and II prevail. On the contrary, the situation is alarming in the upper stream area of the Rakovnický Brook where intensive agricultural activities prevail. Reaches in the middle course, in the predominantly agricultural landscape, show strong anthropogenic impact, as well. Reaches found in the Rakovník city urban area and in the Krrivoklát community are classified as ES IV, both due to channel modification, only partial existence of the riparian belt, and due to considerable transformation of flood plain because of continuous built-up area and roads (Matoušková 2003).

The Liběchovka River basin presents a geomorphologically varied relief of Polomené hory (Polomené Mountains). Slowly changing reaches of lowland nature prevail; nevertheless, reaches showing marked gradients are found in this river basin, as well. At present, the flood plain is free of significant anthropogenic activities; however, as few as 50 years ago, it was used for agricultural activities. The river basin is thus interesting from the viewpoint of monitoring possible development of river habitats upon withdrawal of agricultural activities. Ecomorphological state in the Liběchovka River basin can be classified as favourable, as $77 \%$ of the total length of the reaches mapped was assessed as ES I and II. Upper stream reaches are concerned, as well as almost the whole middle course of the Liběchovka River. Reaches classified as ES III are bound to areas used for agricultural activities. Riparian belts exist, however, their composition as well as structure is modified. ES IV is found especially in areas where dispersed built-up areas prevail in the flood plain. Riparian belt is not developed as a rule. ES V differs from ES IV especially in land use in the flood plain where unlike dispersed built-up areas, continuous built-up zones prevail, as well as industrial objects or roads (Š́pek 2006).

\section{Comparative Analysis of the Methods Applied}

All the methods applied showed the capacity to identify natural reaches and moderate to completely change reaches and provided precious information on the river habitat state. However, they are varied from the viewpoint of the number of parameters, number of monitored zones, time and knowledge demands on the assessment performed (see Table 2). 
Tab. 4 - Features of applied assessment methods

\begin{tabular}{|c|c|c|c|c|}
\hline Method & EcoRivHab & $\mathrm{RBP}$ & $\begin{array}{l}\text { LAWA-Field } \\
\text { Survey }\end{array}$ & $\begin{array}{c}\text { LAWA- } \\
\text { Overview Survey }\end{array}$ \\
\hline $\begin{array}{l}\text { Number of } \\
\text { parameters } \\
\text { Monitored zones } \\
\text { Length of reaches } \\
\text { Point assessment } \\
\text { Number of classes } \\
\text { Accent on } \\
\text { hydromorphology } \\
\text { Slope condition } \\
\text { Water quality }\end{array}$ & $\begin{array}{c}31 \\
\text { channel, riparian } \\
\text { belt, flood plain } \\
\text { heterogeneous } \\
5 \\
5 \\
\\
\text { yes } \\
\text { yes } \\
\text { yes }\end{array}$ & $\begin{array}{c}10 \\
\text { channel, riparian } \\
\text { belt } \\
\\
\text { heterogeneous } \\
20 \\
4 \\
\\
\text { no } \\
\text { yes } \\
\text { yes }\end{array}$ & $\begin{array}{c}25 \\
\text { channel, river } \\
\text { banks, riparian } \\
\text { belt } \\
\text { homogeneous } \\
7 \\
7 \\
\\
\text { yes } \\
\text { no } \\
\text { no }\end{array}$ & $\begin{array}{c}17 \\
\text { channel, river } \\
\text { banks, riparian } \\
\text { belt } \\
\text { homogeneous } \\
5 \\
5 \\
\\
\text { yes } \\
\text { no } \\
\text { no }\end{array}$ \\
\hline
\end{tabular}

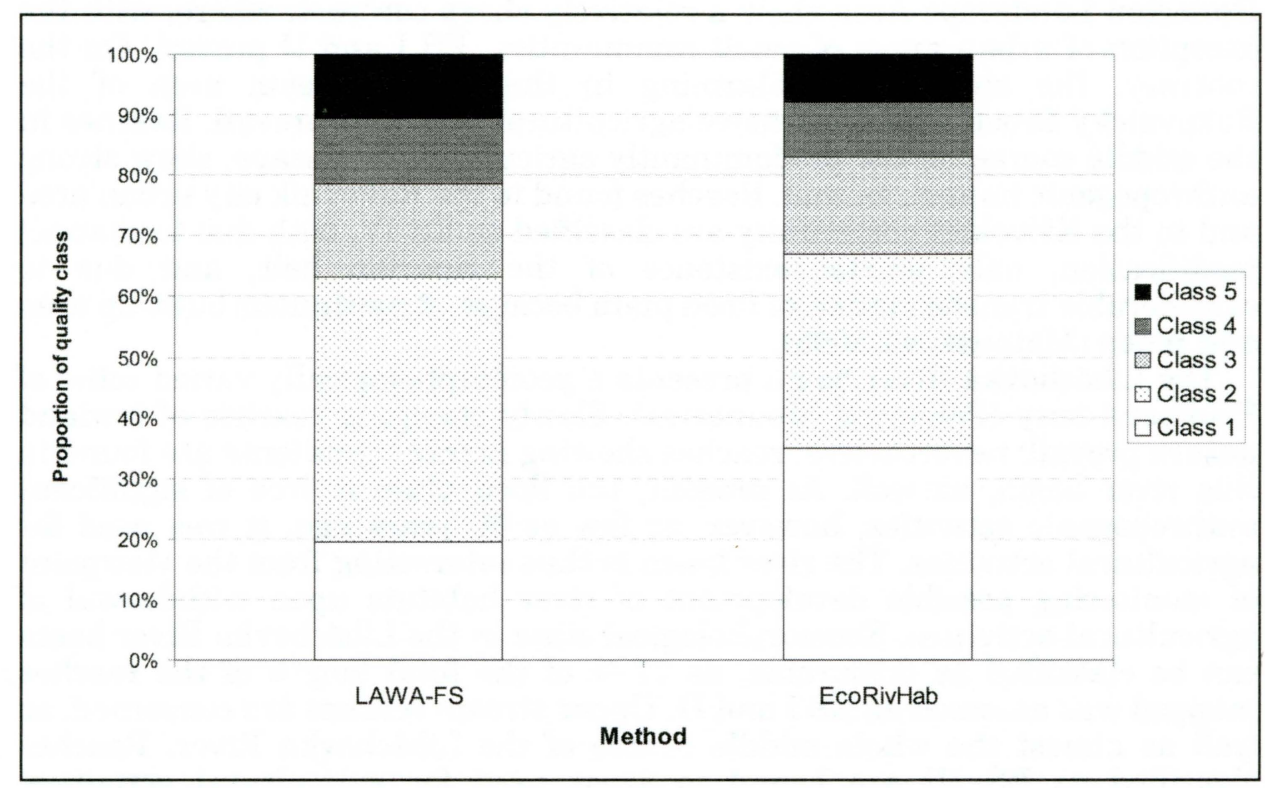

Fig. 4 - Assessment of the habitat quality of the Rolava main stream using the methods EcoRivHab and LAWA-FS (comparative analysis), mapping Lelut, analysis Matoušková

Qualitatively identical results were brought especially by the methods EcoRivHab and RBP. Both methods are similar. The method RBP is less time demanding as it assesses the watercourse habitat based on 10 hydromorphological parameters. Greater differences were found between LAWA-Field Survey (FS) and the methods EcoRivHab \& RBP, which is given by certain preference of the negative anthropogenic impact on the modification rate of the channel in the case of the method LAWA-FS. As for EcoRivHab, every one of the zones assessed participates in the same level in the total assessment of the watercourse habitat quality, i.e. by one third. In the case of LAWA-FS, the riverbed and the bank are assessed separately. On the contrary, the riparian belt and flood plain are assessed jointly. Certain differences in the resulting assessment can also occur due to different 
delimiting of the mapped reaches. The method LAWA-FS is more time demanding due to mapping in $100 \mathrm{~m}$ reaches, however, it cannot be stated clearly that it provides greater precision as in the relatively short length of the reaches assessed; merging of two markedly different habitats may occur. However, upon conversion of the 7 resulting ecomorphological classes of LAWA to 5 as required by WFD, similar results were obtained as in other assessments, see Figure 4. The method LAWA-Overview Survey (Kern et al. 2002 ) is based on processing of distance data and information available from watercourse administrators. Its outputs seem to be least precise from the viewpoint of application to small streams. It is suitable especially for largescale monitoring of watercourse habitats (Table 4). During our application occurred problems with insufficient evidence of necessary data and additional field mapping were done.

Comparison of the assessment system of individual methods and WFD requirements was performed, as well. As for the method EcoRivHab, the classification scale, i.e. 5 ecomorphological classes, shows full compatibility with the WFD assessment system, i.e. 5 quality classes: ES I - 1 class unchanged (reference condition); ES II - 2 class slightly changed; ES III - 3 class moderately changed; ES IV - 4 class strongly changed; ES V - 5 class completely changed. Nevertheless, unlike WFD requirements the method EcoRivHab does not include quantitative assessment of the hydrological regime directly; however, this assessment is recommended to be performed in the initial phase of investigation. On the contrary, it includes the following parameters: river valley type; waste water outlets; and surface water quality state.

\section{Conclusions}

An advantage of the formulated method EcoRivHab is a complex view of the river habitat quality from the viewpoint of the parameters assessed, but also from the viewpoint of the space, i.e. taking account of a broader background of the stream. Furthermore, relatively simple and clear quantification of outputs can be presented, as well as the possibility of mutual comparative analysis of the outputs obtained. A certain disadvantage is formed by the necessary generalization of the water ecosystem characteristics within the framework of the parameters defined. The demanding nature of field investigation should be mentioned, as well, compared to methods based only on distance data utilization. Nevertheless, the time demands are manifested in higher quality and topicality of the outputs obtained. Negative characteristics also include a certain level of subjective assessment of the mapper in the field monitoring phase. The subjectivity can be eliminated by sufficient training of the mappers, necessary photodocumentation of the field investigation phase, and subsequent checking of the field outputs obtained.

Out of the outputs of the field mapping of watercourses performed it follows that the definition of references states is optimal based on local situation, i.e. if the given watercourse or its near equivalent in the given relief type flows, for example, through protected landscape. The drainage measures taken in the agricultural land and modifications of channel related thereto have a negative impact on the nature of watercourse habitats; ES III and IV was recorded predominantly. Achievement of a good ecological state is realistic provided that the necessary minimum space for riparian belt is provided, and 
that revitalization measures are taken according to the locality type. River habitats in urban areas of communities are usually modified in a significant extent (ES IV and V prevail). Improvement of the ecohydrological state is problematic here as the modifications performed are connected with continuous built-up area in the riparian belt and flood plain, with existence of flood protection measures and artificial grounds. Certain improvement of the hydromorphological state of the channel can be achieved, for example, by application of biotechnical modifications. However, qualitative parameters of surface water quality can certainly be improved.

Methods based on field investigation can be suitably applied in assessment of the ecohydrological state of small watercourses, especially due to the quality and informative value of the results obtained. In the case of areal monitoring of significant watercourses, distance data available can be utilized. However, quality of the outputs obtained should be retested using field investigation. A powerful and efficient monitoring programme has to be created, to be used to assess watercourse habitat quality in Czechia. Cooperation with neighbouring EU countries in its creation is advisable, on the level of integrated river basins at best. The outputs obtained shall serve not only to fulfil WFD requirements but they will also provide an outstanding source of information for integrated checking, monitoring, planning, protection and possible revitalization of streams.

Acknowledgements are hereby expressed to students of the Department of Physical Geography and Geoecology of Faculty of Science, Charles University in Prague who have been engaged actively in ecomorphological monitoring. Thanks go also to Prof. Jörg Matchullat and Dr. Annett Weiss from Technische Universitaet Freiberg for present cooperation.

\section{References:}

BARBOUR, T. et al. (1999): Rapid Bioassessment Protocols For Use in Streams and Wadeable Rivers.USEPA, Washington, $339 \mathrm{p}$.

BICANOVÁ, M. (2005): Použití metody ekomorfologického monitoringu v povodí Košínského potoka s využitím nástrojů GIS. Diplomová práce, PřF UK v Praze, 108 p.

CEN (2002): A guidance standard for assessing the hydromorphological features of rivers. CEN TC 230/WG 2/TG 5: N32. May 2002, $21 \mathrm{p}$.

ČSN EN 14614 (2005): Jakost vod - Návod pro hodnocení hydromorfologických charakteristik.. Vydavatelství norem. Praha.

DVOŘÁ, M. (2008) Hodnocení kvality habitatu antropogenně ovlivněných vodních toků aplikace na modelovém povodí Bíliny. Diplomová práce, PřF UK v Praze, 141 p.

EN 14614 (2004): Water quality - Guidance standard for assessing the hydromorphological features of rivers. November 2004.

European Commission (2000): Directive 2000/60/EC of the European Parliament and of the Council of 23 October 2000 establishing a framework for Community action in the field of water policy. Official Journal of the European Communities, L327, $77 \mathrm{p}$.

KERN, K., FLEISCHHACKER, T., SOMMER, M, KINDER, M. (2002): Ecomorphological survey of large rivers - Monitoring and assessment of physical habitat conditions and its relevance to biodiversity. Large Rivers, 13, No. 1-2, pp. 1-28.

LAWA. (2000): Gewässerstrukturgütekartierung in der Bundesrepublik Deutschland Verfahren für kleine und mittelgroße Fließgewässer. Empfehlung. Januar 2000. Länderarbeitsgemeinschaft Wasser.

LELUT, J. (2007): Vodohospodářské revitalizace na podkladě ekomorfologického 
monitoringu vodních toků. Diplomová práce, PřF UK v Praze, Praha, 140 p.

MATOUŠKOVÁ, M. (2003): Ekohydrologický monitoring vodních toků jako podklad pro revitalizaci vodních toků. Disertační práce, PřF UK v Praze, Praha, 219 p.

MATOUŠKOVÁ, M. (2004): Ecohydrological monitoring of the river habitat quality. Geografie-Sborník CGS, 109, No. 2, pp. 105-116.

MATOUŠKOVÁ, M. (2007): Ekohydrologický monitoring vodních toků v kontextu Rámcové směrnice ochrany vod EU. Závěrečná výzkumná zpráva projektu GAČR č. 205/02/P102, PřF UK v Praze a GAČR, Praha, 18 p.

MATOUŠKOVÁ, M., MATTAS, D. (2003): Hydroekologické hodnocení vodních toků. Vodní hospodár̆ství, 10, pp. 279-282.

ŠILHANOVÁ, V. (2007): Ekomorfologický monitoring v povodí Klíčavy. Balařská práce, PřF UK v Praze, Praha, 44 p.

ŠÍPEK, V. (2006): Ekomorfologické hodnocení kvality habitatu vodních toků v povodí Liběchovky. Diplomová práce, PřF UK v Praze, Praha, 114 p.

VONDRA, F. (2006): Ekomorfologický monitoring v povodí horní Blanice. Diplomová práce, PřF UK v Praze, $102 \mathrm{p}$.

WEISS, A., MATOUŠKOVÁ, M., MATSCHULLAT, J. (2007): Hydromorphological assessment within the EU-Water Framework Directive - Trans-boundary cooperation and application in to different water basins. Hydrobiologica, DOO 10.1007/s10750-0079247-2.

\section{Shrnutí}

\section{HODNOCENÍ KVALITY HABITATU VODNÍCH TOKU゚ V KONTEXTU EVROPSKÉ RÁMCOVÉ SMĚRNICE O VODNÍ POLITICE: APLIKACE V ROZMANITÝCH POVODÍ V ČESKU}

Příspěvek představuje metodu ekomorfologického hodnocení kvality habitatu vodních toků EcoRivHab založenou na terénním průzkumu s možným využitím distačních dat, která je nástrojem pro hodnocení stavu vodních toků s důrazem na hydromorfologické charakteristiky koryt vodních toků, ekohydrologický stav př́íbřežní zóny a údolní nivy. Předpokladem je definice lokálního referenčního stavu habitatu vodního toku v daném fyziografickém regionu. Hlavním cílem výzkumu bylo objektivní vyhodnocení ekohydromorfologického stavu vodních toků, identifikace úsekủ, které splňují tzv. dobrý ekologický stav, zároveň nalezení silně antropogenně ovlivněných úseků vodních toků, stejně tak jako nalezení lokalit s přírodním, či přírodě blízkým habitatem vodních ekosystémů. Souhrnný ekohydrologický stav vodních toků byl charakterizován pěti stupni (I.-V. ES), což je plně kompatibilní s hodnocením kvality vodních útvarů v kontextu s Rámcovou směrnicí o vodní politice EU.

Pro zajištění objektivity byly $\mathrm{v}$ jednotlivých modelových povodí rovněž testovány zahraniční metody: Gewässerstrukturgütekartierung LAWA - Field Survey (LAWA, 2000), LAWA- Overview Survey (Kern a kol., 2002), Rapid Bioassessment Protocol - RBP (Barbour a kol., 1999), Channel Assessment Prodcedure Guidebook - CAP (Ministery of Forest BC, 1996) a byla provedena srovnávací analýza získaných výstupů.

Jako modelová povodí pro hodnocení kvality habitatu vodních toků byla vybrána povodí: horní Blanice, Rolava, Kř̀emelná, Liběchovka, Košínský potok, Rakovnický potok, Klíčava a Bílina. Zvolená povodí svým charakterem dobře reprezentují geografickou rozmanitost reliéfu Česka a jsou odlišná mírou ovlivnění člověkem. Celkově bylo zmapováno přibližně $450 \mathrm{~km}$ vodních toků.

Z provedeného mapování ve všech zájmových povodí vyplývá, že nejlepší ekohydrologický stav vykazují povodí horní Blanice, Klíčavy a Liběchovky. Přibližně $80 \%$ představují úseky v I. a II. ES, což podmíněno jejich geografickou polohou, značnou rozlohou chráněných území a nízkým podílem antropogenních aktivit. Povodí Rolavy, Košínského potoka a Rakovnického potoka vykazují vyšší stupeň antropogenní modifikace. V nedobrém ekohydrologickém stavu se nachází 10-25\% z celkové délky mapovaných úseků (IV. a V. ES). Jedná se jednoznačně o úseky, které jsou vázány na antropogenní aktivity v povodí. Výjimečné postavení zaujímá povodí Bíliny, úseky se zcela nevyhovujícím stavem, tj. IV. a V. ES představují $51 \%$ celkové délky toku.

Pro hodnocení ekohydrologického stavu drobných vodních toků je vhodné využít metody založené na terénním průzkumu, především z důvodu kvality a vypovídající schopnosti získaných výsledků. $\mathrm{V}$ případě plošného monitoringu významných vodních toků je možné vy- 
užít dostupných distančních podkladů. Měla by však být zpětně ověřena kvalita získaných výstupů pomocí terénního průzkumu.

Obr. 1 - Lokalizace zájmových území ekomorfologického monitoringu.

Obr. 2 - Ekomorfologický stav vodních útvarů v zájmových povodí s využitím metody EcoRivHab. Terénní mapování a analýza: Bicanová (2005), Dvořák (2008), Lelut (2007), Matoušková (2003), Šilhánová (2007), Šípek (2006) a Vondra (2006).

Obr. 3 - Hodnocení ekomorfologického stavu vodních útvarů pomocí metody EcoRivHab v povodích s rozmanitým reliéfem a odlišným využitím krajiny: povodí Rolavy (horský až podhorský typ vodního toku, Rakovnický potok (pahorkatinný tok), Liběchovka (nížinný tok). Terénní mapování a vyhodnocení: Lelut (2007), Matoušková (2003), Sípek (2006).

Obr. 4 - Hodnocení kvality habitatu hlavního toku Rolavy s využitím metod EcoRivHab a LAWA-FS (srovnávací analýza), mapování Lelut, analýza Matoušková.

Author is with Charles University in Prague, Faculty of Science, Department of Physical Geography and Geoecology, Albertov 6, 128 43, Praha 2, Czechia;

e-mail: matouskova@natur.cuni.cz.

Arrived to the editorial board on April 11, 2008 